\title{
Nasopharyngeal Cancer pM1 TNM Finding v8
}

National Cancer Institute

\section{Source}

National Cancer Institute. Nasopharyngeal Cancer pM1 TNM Finding v8. NCI Thesaurus.

Code C132810.

Nasopharyngeal cancer with distant metastasis. (from AJCC 8th Ed.) 